\title{
THE EARLY TEMPLE ARCHITECTURE OF KAKATIYAS
}

\author{
${ }^{1}$ K. Mehar Kumar, ${ }^{2}$ Dr. K.Mrutyunjaya Rao \\ ${ }^{1}$ Academic Consultant in Architecture, School of Planning \& Architecture, \\ Dr. YSR Architecture and Fine Arts University, Kadapa, Andhra Pradesh \\ ${ }^{2}$ Assistant Professor, Dept of Fine Arts, Yogi Vemana University, Kadapa, Andhra Pradesh.
}

Article DOI: $\underline{\text { https://doi.org/10.36713/epra7588 }}$

DOI No: 10.36713/epra7588

\begin{abstract}
The Telangana region experienced a golden age during the reign of the Kakatiya dynasty, which ruled from 1083 A.D. to 1323 AD for years of today's Andhra Pradesh and most of Telangana. Rudrama Devi and Prataparudra II were outstanding rulers of the Kakatiya dynasty. The dynasty was weakened by Malik Kafur's offensive in 1309 A.D and disbanded after Mohammed Bin Tughlaq's army defeated Prataparudra in 1323A.D.. Firstly, study focusses on temple styles of a Kakatiya Dynasty in Telangana that includes architectural aspects, type of temple styles followed in Telangana. Secondly the study focusses on temple Architecture developments taken place during Kakatiya Dynasty in Telangana. The temples and portals of Kakatiya are excellent examples of the originality of architecture, structure and sculpture. All Kakatiya temples were dedicated to Shiva. By discussing of past era of Kakatiya Temple Architecture will get the Temples scenario took place in Telangana. This paper made an attempt is made to discuss about Temple Architecture styles built around Telangana under the Kakatiya rule.
\end{abstract}

KEY WORDS: Chalukyas Architecture, Chandrasila, Upapitha Kakatiya, , structure

\section{INTRODUCTION}

Though there were many regional styles of temple architecture existed in medieval India the Telangana style is the most distinguished. This style covered entire Telangana region as prominent style and extended into Andhra region. But it is interesting to know at the same time art and architecture in Andhra is highly influenced the Chola and Vijayanagar at later times. Simultaneously Telangana region is highly influenced by Chalukyan style and continued so on. This style of temple architecture is distinctively prevailed from the $11^{\text {th }}$ century A,D. coinciding of Kakatiya dynasty and their overlords Kalyani Chalukyas ${ }^{1}$. The influx of artists and architects from Karnataka to this region as this area under the control of Kalyani Chalukyas. This caused to witness the sudden appearance of distinguished features of architecture such as formal and decorative, though have no contacts with the earlier styles of this area namely
Sapadalaksha or Kandurnadu ${ }^{2}$ It is attempted to study the architecture of this region from 1000 A.D to 1163 A.D as it was under the impact of Chalukyan reign. A few early Chalukyan temples found at Alampur in the Mahaboobnagar district deserve the attention ${ }^{3}$. Scholars like Soundara Rajan expressed that the Alampur temples has similarities with Papanadha and Galugunadha temples at Pattadakal. The same scholar expressed that the Alampur temples are enriched by Chalukyan architectural and structural devices as elaborated in succeeded by the Rashtrakuta stage $^{4}$. An eminent authority in Indian architecture like Brown states that these temples indicates the development of the main early Chalukyan style. Scholar like M. Rama Rao made a detail comparison between the Alampur, Satyavolu, and Mahanandi groups of temples in Andhradesa and Pattadakal and Aihole groups of temples in Northern Karnataka and pointed out the items of similarity and difference ${ }^{5}$. One 
clinching fact that all these temples have curvilinear vimana crowned by Amalaka Sikhara with a sukhasana projecting in front and no other early Deccan dynasty is known to have raised this type of Vimana excepting the early Chalukyas. Further, as Brown has rightly said, most of the Alampur temples resemble the Papanadha temple of Pattadakal. Soundara Rajan also admitted that they are akin to Papanadha and Galagunatha temples. The Thummayaneru grant of PulakesinII shows that Calukya-visaya containing parts of Mahabubnagar and Kurnool district was included in his dominions. Other records show other parts of these two districts were in the Calukya-visaya and Vanguravadi- visaya ${ }^{6}$. An inscription at Alampur on the foot wall of the bank of the river Tungabadra mentions the erection of that prakara in the eighteenth year of the rule of early Chalukyan King, Vijayaditya II. This shows these temples ere all raised by this date and fort was built in order to protect them. For this reason and on the basis of stylistic similarities the Galagunatha and Papanath temples and these groups of shrines have to be assigned to early eighth century A.D. Soundara Rajan made a remarkable suggestion, obviously because Satyavolu temples do not conform entirely to the plan of Aihole temple and it was made sure that the satyavolu temples were raised under Eastern Chalukyan patronage. The temples of Alampur, Mahanandi at Kurnool, Satyavolu briefly noticed so far, are of great significance. They are undoubtedly early Chalukyan in main as indicated by their Vimanas and few other common features. But they exhibit many variations in plan and other details. These temples are the result of the local variation of the main early Chalukyan style and some of them like Svargabrahma and Balabrahma have added to the beauty and elegance of the style. They are the distinct contribution to architectural experiments in early Deccan.

The combined Andhradesa made a valuable contributions during the period of rule of Kakatiyas of Warangal (1000A.D to 1323A.D). The Suryanarayana and Narasimha temple at Alampur, the Pacchala Someswara temple at Panagal, Chennakesava temple at Gangapur, Ramalingeswara Temple at Nandikandi, Agasthyeswara temple at Aihole and Someswara temple at Kulupak are ascribed to the afore cited period which have the more Chalukyan impact. Before entering into the discussion on the architectural aspects of $11^{\text {th }}$ century temples it is contextual to have a review of the architectural features of Rashtrakuta period to under the developments in architectural feature that followed on. Papanasi, Maremunnagala, Panchalingala, Alampur, and Vemulavada temples built in Rashtrakuta period. The Maremunnagala and
Papanasi temples are featured with common Ranga mandapa featured of trikuta plan. The other temples are comprised mukha mandapa, antarala, and garbhagriha, and Nandi mandapa are forming integral part of this scheme as we notice at Bhimeswara Temple at Vemulavada. The bases are either manca type, or a mixture of pala and pratabhandha types. The manca type is seen at Panchalingala, Merugumalla, Alampur, Papanasi etc. The latter is observed at Bhimeswara temple at Vemulavada and Alvanipalli. Further the use of upapitha adopted to Bhimeswara temple at Vemulavada. In most of these temple's walls are plain with a niche. The wall pattern thus remained simple. Among the super structural forms, we notice phamsana, Vimana, Salakara, and Gajapristaakara. The pillars are of chitrakhanda type. The doorways are triple jammed, richly, and lavishly adorned with vyala stamba, lata patra. We may notice nidhi figure and Chandrasila besides the Ganga -Yamuna high relief sculpture on both sides of the doorjambs. Chandrasila (moon slab) is generally found in front of the doorstep on the floor of antarala and Garbhagruha. Best examples of ornamentals member are noticed in the temples of Hanumakonda, Warangal, Jakaram, Nagunuru, Pillalamarri, Kusumanchi etc. It is carved generally in high relief and composed of two sections. The lower section is the base normally it is in the form of Pattika. The upper section is in semi circle or ardhaChandra in general design ${ }^{7}$.

Usually, Ganga sculpture will be on right side and Yamuna on the left side. The ceilings are flat type and sometimes lozenge shaped ceiling are used. Though the architectural feature of $11^{\text {th }}$ and $12^{\text {th }}$ centuries are attributed to the typical Dravidian styles while the Phamsana form has continued as favorite element in the preceding centuries, the Bhumija form also makes its appearance ${ }^{8}$ on plan the temples have open ranga mandapa, antarala, garbhagriha instances of the temples having a mukha mandapa are also encountered as in the Suryanarayana swami temple at Alampur, The Chennakesava swami temple at Gangapur. Trikuta form is also found. However, the variation to the trikuta is shown by placing the shrines at the back of the mukha mandapa, instead of placing on either side of mukha mandapa. This typical feature seen at Panagal, Ainole and Alampur. In the Chennakesava temple the panchayatana layout is noticed at Chennakesava temple at Gangapur. Depending upon the form of the temple the plan of garbhagriha is made star shaped, this is found at Nandikandi where the temple is of Bhumija form. The proliferation of the wall beyond the manasutra line also encountered in the temples of Panagal, Nandikandi, Gangapur. 
Generally, these temples stand on low plinth which is a typical characteristic of Chalukyan style but the temple of Gangapur and Nandikandi are exception built on high plinth. When it is used, this is in the manner of jagathi of nagara style. The tenth century temples in Telangana region have high Upapitha typical to the Dravidian style while this has Upana, Kantha, Pattika, the Gangapur and Nandikandi temples have Jagathi possessing a series of Bhittis devoid of any decorative carving. This new feature was vogue in Kuntala as well as Lakkundi. The bases depending up on the form of the temple depends on either an Adhisthana or pita. The former is seen at temples at Papanasi, Ainole, Punnole etc. the latter is evident at temples at Malleswaram, Alvanipalli etc. At Nandikandi we have pitha possessing bhatta, jadyakumbha, antarapatra, Kapotali while in the ranga mandapa part the Karnika is introduced. This actually tripatta Kumuda which acquired the shape of Karnika by virtue of its compressed and knife edged form. Though early shrines at Panagal, Gangapur are of Dravidian style, they also reveal the change in the form of the mouldings as well. Here we have usual upana, jagathi, and Karnika and kapota. This transformation is lucid in the thousand pillared temples at Hanumakonda ${ }^{9}$. The proportions and form of moldings are closer to the bases in the temple at Lakkundi, Gudur etc. by this the fabric of the base is completely different with Dravidian style or for that matter the styles of the earlier period in this region.

The important change is seen in the treatment of wall which certainly bestows individuality to the style. During this period, we notice three kinds of wall. In the first type, the wall is composed of intended buttresses like the massive pillar in its look and are faceted. The Kutasthamba enframed in makara torana occupies dimly lighted recessed parts of the wall. The shrine models used in these are Phamsana form and are narrow and elongated. The makara torana spiring from the end of Kutasthamba converges at the point of Kalasa. Similar decorative elements are adopted in the temples of Kuntala region which however differ in the aspects of rich décor and bulging shape as opposed to the slender, elongated, and abbreviated form that found in the Telangana region. In the top portion of the buttress, he widely differentiated utter element repetitive in its employment is also found. This type of wall also noticed in Pacchala Someswara temple at Panagal. while this type of wall is not appeared before the $11^{\text {th }}$ century A.D., in Telangana region. Its appearance along with a new type of pitha underlies the sudden emergence of new style. However, the sources for this type can be found in the $11^{\text {th }}$ century temples of Kuntala region, particularly Kasiviswara temple at
Lakkundi, the Galeswaranath temple at Galaganath and Ramalingeswara temple at Gudur etc.

In another type of wall pattern, the wall divided Karna Pratiratha, Konika and Bhadra all are proliferating parts. Each part is framed with slender pilasters that support a phamsana super structure or makara torana. The upper part of the wall is treated with repetitive bracket highly differentiated as noticed in another pattern. This type of temples belongs to Gangapur and Panagal. The Chennakesava temple at Gangapur is the most remarkable and splendid example for its proportions lack any kind of decorative carving bestows an architectonic character. This pattern has been adopted form Kuntala: the temples at Begali, Nilagonda, Kuravatti, Huvinahadapalli, Lakkundi etc. of the 10th -11 th centuries $\mathrm{AD}$ is the case in point.

The simple walls are lacking niches or pilasters also encountered. The same could be noticed in the Chennakesava temple at Pudur, the Suryanarayana swamy and Narasimha temple at Alampur.

The superstructure of in the temples of this period belongs to the three varieties namely Vimana, Phamsana, Bhumija forms. Of these the Vimana is a native to this region. Pacchala Someswaraswami temple and Siva temple are the best example. In these haras of the talas are indistinct and constituent elements are highly faceted. The Kutas are prominent though highly abbreviated. The superstructures are heavy and emphasize the basal width. The square sikhara is favored. The Phamsana form is instance at Alampur, Pudur, Papanasi etc ${ }^{\mathbf{1 0}}$. The simple stepped pyramidal superstructures with sukhasana in the front which became popular in proceeding centuries.

Bhumija form is noticed in the Ramalinga swamy temples and Nandikandi. It is the earliest example of tribhumi class of the Telangana region. In this conspicuous is the absence of mala element, a feature typical to Bhumija form. The srngas on the other hand are distinctive and their position is set on the buttress that ascend to the summit where the star shaped neck element terminated the sikhara. In the srnga element, the miniature shrines are of latina form which is known as Nagara karma according to the vastu texts. The crowning elements of sikhara are inverted skanda, the Phalaka, griva, followed by the ganta and kalasa. The form and sequence are exceptional and distinguished form Kuntala. The Sukhasana reaches up to the second bhoomi.

Though in Kuntala, no standing temple of Bhumija form is reported to date, we have several representations of the Bhumija sikhara. The Kasiviswaswara temple of early 11 th century at Lakkundi is the most remarkable of its kind. In this 
example the mala element with surasena at the base four srnga courses of Nagarakarma class in three stories are noticed. The prominence of ganta elements is noteworthy is also noteworthy. the characteristic feature is the pilaster part of the Kutasthamba is subdued in height. The Uttara part is highlighted in the srnga at Nandikandi which is indistinct to the Kuntala examples. The lack of mala element in the Bhumija sikhara at Nandikandi is also aberrant example. In the later phase the mala element in the Bhumija sikhara is seen present at Pillalamarri and Ghanapur. Once again, this form is borrowed from Kuntala.

Coming to the architectural elements, the doorway, the pillar, and the ceiling deserve consideration. The concept of erecting fence can be traced form Vedic literature to fence around the cattle or entire village. This element gave inspiration to the Buddhist in later times and been adopted by the early Chalukyan architect who erected a free standing torana in front of kuntigudi group of temples at Ainole ${ }^{11}$. It is interested to note that toranas as entrance architraves were first innovated by the Rashtrakutas as seen at the Pratoli of Alampur followed by Kalyana Chalukyas in Telangana region $^{\mathbf{1 2}}$. Later torana attained distinctive feature of Kakatiya rulers, developer master over it. it stood as at top section of marvel of Kakatiya art in later times.

Chitrakhanda pillar in highly favored in all the temple of this period. New motif like tracery like ornamental motif is found on the middle portion of the shaft at Nandikandi, Panagal temples. This is the motif frequently found in the Sennadesa temples. The use of miniature temples models of Phamsana type came in vogue in the $10^{\text {th }}$ century A.D. as seen at Vemulavada and in the Nandikandi temple of $11^{\text {th }}$ century A.D. The Vyala riders are also found in the brackets. Another pillar type that is employed in this period is Vardhamana type. This is also an antecedent in Kuntala region, particularly Lakkundi.

The richly carved doorways having three or five jambs are invariably found. Thse jambs are decorated with circular lata motifs with ganas, stamba, vyala, lata patra and finally rupa. The over door is always fashioned like a chadya and religious there are carved on it. The mannerism of Kuntala carving is seen the decorative carving on the jambs of the temples.

The ceilings are the normally flat types and carry Shiva as Nataraja and ashtadikpalas, lozenge shaped ceilings are also frequently employed. We have referred to the earlier about the influx of the artists and architect Pusana, son of Betoja, is mentioned in inscription at Nandikandi. Though this the only instance of the name of the artist found in the inscriptions during the $11^{\text {th }}$ century A.D., we may conclude by very great impact of architectural conventions that several architects came over Telangana region. The compositional examination and political history of this area that may uphold above ends.

\section{REFERENCES}

1. Yazdani $G(1960)$. The early History of the Deccan , London , $p$.

2. Sapadalaksa corresponds to the present districts of Nizamabad, Karimnagar while the Kundurunadu corresponds modern districts of Nalgonda and Mahabubnagar

3. M. RamaRao (1974) , Early Chalukyan Temples,Tirupati p.4.

4. Archeological survey India, Early Hindu temples, p.27.

5. Rama Rao M., Early Chalukyan Architecture-A review in Journ. Ind.Hist. Vol XLI pt 2, pp 431-457

6. JAR X.1 pp27-46, EI XXXII, pp. 175-184

7. B.Sathyanarayana Singh(1999), Art and Architecture of Kakatiyas, Bharatiya Kala Prakashan, New Delhi, p.126

8. The term Phamsana means stepped pyramidical superstructure.

9. Radhakrishna Sharma. M, Temples of Telnigana, Hyderabad 1972, pp.77-83

10. Dr. Rajendra Prasad B(1970), Papanasi Devalayamulu, Bharati, pp. 20-24.

11. R.S. Gupta(1967),The Art and Archaeology of Ainole, Bombay, pl.47

12. B. Rajendra Prasad(1980), Chalukyan temples of Andhradesa, Delhi, p.83. 